\title{
THE STATUS OF AESTHETICS TODAY
}

Katya Mandoki

Metropolitan Autonomous University

\section{A B S T R A C T}

In this paper I argue for the possibility of expanding the field of aesthetics not only beyond art and beauty but also beyond everyday aesthetics (or prosaics) centered in human sensibility. This implies considering sensibility or aesthesis in all live beings to understand the vastness of bio-aesthetics. Part of this query is zoo-aesthetics. We have such growing evidence, enriched day by day, that animals are capable of creating, recreating, imitating, enjoying, exhibiting and expressing sensibility or aesthetic taste in various forms that it is harder to deny the more we record and witness their behavior. Moreover, as there are various artistic genres, we can equally speak of similar genres in zoo-poetics, namely: a) musical b) visual (both architectonic and decorative), c) drama, and d) dance.

Are females enamored by the male bat or bird mating song? Do peahens feel pleasure at the sight of a male peacock's tail? As Nagel asked 'what is it like to be a bat?' I would really like to know what it is like to be a peahen.

This full inquiry is being published in The indispensable excess of the aesthetics: evolution of sensibility in nature. (Lexington 2015)

KEY WORDS

EVOLUTIONARY AESTHETICS

DARWIN

BIOSEMIOTICS

ZOO-POETICS

AESTHESIS

ZOO-AESTHETICS

EVOLUTION 


\section{THE ANOMALY}

The enigma of the peacock, a singular aesthetic and absolutely excessive event in nature, was so unfathomable that made Darwin literally sick. No wonder. Such magnificent peacock tail casted doubt on the process of random mutation and natural selection as the sole explanatory principle of evolution in The Origin of Species. This principle predicts that a short-tailed peacock would have been selected over a long tailed simply because it is more practical for survival. So hard to maintain and show off, so dangerously conspicuous to predators and cumbersome in need to escape, requiring more nutrients and more vulnerable to parasites, revealing its flaws to females, this vast tail did not seem to find a coherent explanation in Darwin's theory. Such extravagance became like a ghost that haunted Darwin's paradigm threatening it to collapse. The only possible explanation turned out to be even more extravagant: the aesthetic taste among peahens.

Since aesthetics has been considered the peak of human refinement, this preposterous idea of animals owning a sense of taste was questioned by diverse authors, especially by Darwin's co-author and colleague Alfred R. Wallace who criticized him for attributing sophisticated human emotions to supposedly lower creatures. Yet to this day we have not found a more convincing account.

In this paper I present the results of a research into this problem published in my recent book The Indispensable Excess of the Aesthetic: Evolution of Sensibility in Nature, that just came to light this month published by Rowman and Littlefield. These results have taken me to argue for the need to expand the field of aesthetics not only beyond art and decorative objects, but beyond everyday aesthetics and socio-aesthetics, the subject of my six previous books dedicated to Prosaics or non artistic aesthetics. We must consider the broader manifestation of bio-aesthetics in all live beings to understand the vastness of these splendid phenomena, since aesthesis is the condition for the possibility of life. Solid evidence confirms the existence of animal sensibility, imagination and creativity in what we can clearly call zoo-poetics, examples of which are presented here.

\section{THE PUZZLE}

In 1866, James Shaw published a very brief text in the Athenaeum, 'Feeling of Beauty Among Animals' which was the first essay to openly address the question of animal aesthetics. ${ }^{1}$ This article certainly inspired Darwin who in 1871 and without any philosophical inferiority complex published a section entitled 'The Sense of Beauty' as a serious reflection on this subject in his new book dedicated to sexual selection. ${ }^{2}$ 
And as Greek Tragedy was the paradigmatic example to Aristotle for understanding Poetics, the behavior of peacocks and bower birds was equally so to Darwin for the case of zoo-aesthetics. In a letter to his friend Asa Gray on April 3, 1860 Darwin writes that 'the sight of a feather in a peacock's tail, whenever I gaze at it, makes me sick'. Darwin's sickness turned into a real passion for explaining it. Despite the criticisms and objections even from those who could help him solve it, as his co-author Alfred R. Wallace, Darwin assumed this enormous challenge notwithstanding its great intellectual cost: the effort to write another book The Descent of Man and Selection in Relation to Sex (899 pp.), almost double in size to the Origin of the Species (502 pp.), and the penalty of having to remain almost ignored by academic publishing for a century. In this second text, Darwin confesses that he collected notes on the origin of man with the intention of not publishing them, as merely the slight mention that 'light will be thrown on the origin of man and his history' (Darwin 1859, 254) caused such commotion as to discourage anyone. ${ }^{3}$

By the new version, the process of evolution is due not only to the blind and fierce mechanism of natural selection by random mutations and selective retention of traits in the struggle for survival, but to something different and more radical: The idea that the female of each species could be running the selection process. To top it off, this is done with aesthetic criteria, the superfluous almost by definition. Biology at the hands of the aesthetic whim of females!

This demonstrates Darwin's intellectual honesty, considering his misogynist bias prevalent in the Victorian context, having then the bad taste to write that: 'The chief distinction in the intellectual powers of the two sexes is shown by man's attaining to a higher eminence, in whatever he takes up, than can woman - whether requiring deep thought, reason, or imagination, or merely the use of the senses and hands ". ${ }^{4}$ So the eternal feminine now billed Darwin's prejudice dearly: again as Eve, Lilith, Pandora, Helena of Troy, Cleopatra and Malintzin, it was entirely the female's fault.

\section{THE PUNISHMENT}

Darwin was ridiculed for his idea of female selection and still in 1960, as Trivers notes, scholars took seriously an explanation according to which females were wooed not because they could choose partner but because they were too lazy to mate naturally and were afraid of being touched since when a predator touches them, they die. ${ }^{5}$ Such a theory is false as proven by the highly selective sense of females in various species i.e. Physalaemus postulosus frogs in Michael Ryan's experiment demonstrating that they are able to accurately distinguish the size of the male by the simple croaking tone and therefore select the largest. ${ }^{6}$ 
The female is at the helm of the evolution of multiple species as she requires to be captivated by the male specimen whose particular features she chooses to pass on to the next generation. In many cases, she not even has to wait to be seduced, but goes straight to the male that is most attractive to her and copulates with him.

Just as man can give beauty, according to his standard of taste, to his male poultry, or more strictly can modify the beauty originally acquired by the parent species, can give to the Sebright bantam a new and elegant plumage, an erect and peculiar carriage - so it appears that female birds in a state of nature, have by a long selection of the more attractive males, added to their beauty or other attractive qualities. No doubt this implies powers of discrimination and taste on the part of the female which will at first appear extremely improbable; but by the facts to be adduced hereafter, I hope to be able to show that the females actually have these powers. ${ }^{7}$

This female frivolity implies, therefore, that at stake are not only direct instrumental, practical criteria, but the aesthetic as well. This is a scandal that not only upsets the misogynist bias when recognizing that females drive the evolution of certain species but also offends the sensibility of aestheticians who think the field should circumscribe itself to the study of works of art and the essence beauty. It also puts into question and turns around the evolutionary formula of 'blind mutation and natural selection' to the opposite. What is at work here is a deliberate and very discerning mode of selection. Darwinian functionalism derives, paradoxically, in hedonism and caprice. ${ }^{8}$

\section{THE REWARD: ANIMAL SENSIBILITY}

Females in many species are not forced to mate with the bravest male winning all contests at the birds' public square or lek, but seduced by the most charming. Darwin describes that ' $[t]$ he rock-thrush of Guiana, birds of Paradise, and some others, congregate; and successive males display their gorgeous plumage and perform strange antics before the females, which standing by as spectators, at last choose the most attractive partner.' 9

Given that various animal species proudly display their quality in symmetry, proportion, garb, poise, this points to the fact that somebody, namely the females, must be, and in fact are sensitive to these qualities. It is not merely the case of possessing these qualities, but also of being conscious of it and displaying them proudly. Shaw noted:

I have a black bantam cock and hen. [...]. I have tried him several times with the mirror, he being handsome and having a very pretty rose- 
comb. He never once pecked at his shadow there but walked mincingly and slowly before it on his toes or drew up a foot as he does when one speaks coaxingly to him. ${ }^{10}$

\section{ANIMAL ART?}

Is there animal art? To answer this question we must distinguish between 'art' and 'poiesis', the latter an activity from which the former evolved. 11 Art is institutional, conventional, and framed, as Danto and Dickie have argued. ${ }^{12}$ Consequently, there cannot be animal art. Komar and Melamid's so called 'elefant art' and other similar exhibitions are in fact human forms of entertainment by trained animals to perform certain tricks, as in the circus, not animal art. They are not genuine art because these are not spontaneous and authentic animal forms of expression. One can still propose the serious study of a zoo-poetics if not a zoo-artistics.

Poiesis is the elaboration of artifacts, displays, or messages with particular emphasis on formal qualities, such as a song to a bird call, or a bower to a nest. Many species make artifacts: bird and fish elaborate nests, beavers make dams, bees construct beehives, spiders weave their webs, etc. Formal aspects are involved in all of them because construction and communication depend on morphological constraints. When an additional effort is invested in formal aspects like emphasizing color, symmetry, rhythm, or proportion, we are dealing not only with praxis but with poiesis.

Homo sapiens and Neanderthals both practiced poetics in creating ocher painting, carving bifacial axes, singing, performing, and dancing. This does not mean they were prehistoric artists; what it does mean is that poetics has a very long evolutionary history that transcends our species.

\section{ZOO-POETICS}

We must also distinguish between two modes of zoo-poetics: One is indirect, phylo-genetic poetics, referring, as we shall see, to the visual conformation of the species through many generations as a result of female sexual choice of particular male traits (color, size, brightness, symmetry or composition). The other is direct, onto-genetic poetics, generally performed by males who deliberately construct attractive artifacts like bowers, or decorate nests, and perform antics or dances for their immediate alluring effect. Phylo-poetics centers on the genotype, whereas in onto-poetics, the phenotype is at stake; one relates to what the individual is, and the second to what the individual does. To illustrate the precise meaning of phylo-poetics, I am quoting Darwin when he writes that: '.. if man can in a short time give elegant carriage and 
beauty to his bantams, according to his standard of beauty, I can see no good reason to doubt that female birds, by selecting, during thousands of generations, the most melodious or beautiful males, according to their standard of beauty, might produce a marked effect."'13

We have such vast evidence, enriched day by day, that animals are capable of creating, recreating, imitating, enjoying, exhibiting and expressing sensibility or aesthetic taste in various forms that it is harder to deny the more we record and witness their behavior. Moreover, as there are various artistic genres so we can equally speak of similar genres in zoo-poetics, namely: a) musical b) visual (both architectonic and decorative), c) drama, and d) dance.

\section{MUSIC}

David Rothenberg who researched bird song for more than a decade and has made significant attempts to interact musically with birds, asserts that while bird calls are innate, songs are not. Bird songs are created and learned, exhibit pitch and rhythm 'repeating patterns, themes and variations, impressive virtuosic trills and ornaments, scales and inversions". ${ }^{14}$

Not only birds sing. Toadfish, mice, bats, antelope squirrels, beluga whales, bonobos and humans sing. It is known that male humpback whales' songs, when played to higher frequency, show similar patterns to bird and human songs. Edward O. Wilson reports on the humpback whale the following:

The most elaborate single display known in any animal species may be the song of the humpback whale Megaptera novaengliae. First recognized by W. E. Schevill and later analyzed in some detail by Payne and McVay (1971) the song lasts for intervals of 7 to more than 30 minutes' duration. The really extraordinary fact established by Payne and McVay is that each whale sings its own particular variation of the song, consisting of a very long series of notes, and it is able to repeat the performance indefinitely. Few human singers can sustain a solo of this length and intricacy. The songs are very loud, generating enough volume to be heard clearly through the bottoms of small boats at close range and by hydrophones over distances of kilometers. The notes are eerie yet beautiful to the human ear. Deep basso groans and almost inaudible high soprano squeaks alternate with repetitive squeals that suddenly rise or fall in pitch. ${ }^{15}$

To witness Aristotle's concept of mimesis live, we just need to watch the lyrebird acoustic mimesis of other birds' songs or of mechanical and natural sounds. Mockingbirds do not simply imitate other birds' songs, but they do so according to a pattern as do lyrebirds in a creative combination of mimesis and inventio. 


\section{VISUAL AND SPATIAL}

On visual expression of animal creativity, hummingbirds both camouflage and decorate their nests with lichen and sometimes place an odd feather at the sides to highlight its symmetry.

The best evidence, however, of a taste for the beautiful is afforded by the three genera of Australian bower-birds .... The Satin bowerbird collects gaily-coloured articles, such as the blue tail-feathers of parrakeets, bleached bones and shells, which it sticks between the twigs, or arranges at the entrance. ... These objects are continually re-arranged, and carried about by the birds whilst at play. The bower of the Spotted bower-bird 'is beautifully lined with tall grasses, so disposed that the heads nearly meet, and the decorations are very profuse.' Round stones are used to keep the grass-stems in their proper places, and to make divergent paths leading to the bower. The stones and shells are often brought from a great distance. The Regent bird, as described by Mr. Ramsay, ornaments its short bower with bleached land-shells belonging to five or six species, and with 'berries of various colours, blue, red, and black, which give it when fresh, a very pretty appearance. ${ }^{16}$

In this much contested competition, the Pritzker Architecture Prize goes to orange-crested gardener's bower in the rain forest of New Guinea:

The two openings in front of the hut are connected inside by a semicircular passage. The bird has covered a column between the two openings with dark moss. It is decorated on one side with blue iridescent beetles, in the middle with yellow flowers, and on the other side with broken shells. In front of the bower is a fence plaited from twigs and decorated with brightly colored fruits (sometimes with flowers as well), which forms the boundary of the 'garden'. ${ }^{17}$

\section{DRAMA}

Mimesis, which for Aristotle was the key to art, is an entire zoo-aesthetic dimension across various genres. Flatfish camouflage as sand to escape predators and Transvestite fish disguise as females to fertilize eggs in another male's constructed nest. Insects camouflage themselves as leaves (cyclopetra or chitoniscus feedjeanus), non toxic butterflies mimic toxic ones. Shrimps are capable of bluffing and appearing larger to scare away predators. In a territorial dispute, ants raise their body with their elevated head and abdomen to impress their opponent, and stand as on stilts drumming on the rival's body who after 10-30 seconds gives up defining hierarchy. The beta or Siamese fish keep 
their gill upright during a fight to display fitness by a handicap in breathing and impress their rival. The male stickleback fish zigzags to court the female and the winner of the combat increases its brightness in color to boast its power, while the defeated literally becomes pale. Another genre is the thriller, performed by the Aspidontus taeniatus fish, which dances and pretends to be Labroides dimidiatus, a fish that maintains a mutualist relation with its host by cleaning parasites from the host's scales. Once the host has been fooled, Aspidontus taeniatus attacks and bites it. ${ }^{18}$

Yet, there are those dramaturges with greater inventive. Nominated for best actress in animal drama is the killdeer bird who emits a distress call and flaps her wings simulating being injured to attract the predator away from her nest in her magnificent interpretation of the classic 'Broken-wing act'. For best actor category, the Oscar goes to the wunderpus or mimic octopus capable of masquerading as 20 other species.

\section{DANCE AND ACROBATICS}

Certain birds, such as larks, are masters at acrobatics as they fly plunging down at great speed and do not open their wings until the very last moment to dramatize and exhibit their skill. The Scolopax gallinago flies at high altitude and rapidly descends in a zigzag curve with its tail extended to produce a special sound by the outer feathers. The grouse performs a dance before the female blowing his chest up and extending his tail while turning around to exhibit himself. The cranes move graciously and gratuitously without a particular goal evoking ballet dance. All these are marvelous acrobats and dancers, but no one compares to our winners of this year's contest: for salsa the Bird of Paradise, and for pop style Snowball the cockatoo!

\section{CONCLUSION}

The selection of such exotic luxuries of nature as birds of paradise, pheasants and peacocks have no other explanation than 'aesthetic' taste of females in total rebellion against evolutionary instrumentalism. The peacock phenomenon is a challenge not only to misogyny but to the pragmatic heart and marrow of evolution, because choosing the beautiful rather than useful requires some explanation. In a way, Kant intuited it when he wrote that the beautiful 'directly brings with it a feeling of the furtherance of life" ${ }^{19}$. We owe so much to the females of each species the variety of colors, shapes and ornaments of nature by selecting and cultivating the finest for reproduction that it's about time to thank us! 
Stripping the argument:

1. There is evidence on the preference of certain traits over others in some species that do not appear to relate directly to any useful purpose.

2. There are species that contradict the law of natural selection in that they are focused on the reproduction not precisely of functional fitness.

3. To our knowledge, we have no proof nor can we be sure that there is no sense of 'beauty' in other species, but that their preferences for vivid colors, symmetry, proportion are consistent with human criteria in aesthetic evaluation is a fact.

The main consequence of this approach is that the evolution of creatures appears not to be blind at all but very sharp, sensual and selective to the extent that by contributing to it we are rewarded with the experience of beauty (whatever that means), as well as alerted by the sense of ugliness.

Why do females require beauty to mate? Do they feel pleasure at the sight of a male peacock's tail? How important is the beauty of the male to a peahen if she stays away from him immediately after copulation anyway, as is the case of polygamous peacocks? Is the female cricket moved when listening to the stridulating music of the male? Does she really interpret it as something close to 'beautiful' or something else? Does the peahen admire colors and proportions or rather perform a calculation by phenotype of resistance to parasites and genotype quality indexes? Is the female bat enamored by his mating song? As Nagel asked 'what is it like to be a bat?' I would really like to know, to solve this mystery, what it is like to be a peahen. content/frameset?viewtype=image\&itemID=CUL-DAR84.1.181\&pageseq=1.

Charles Darwin, Descent of Man, and Selection in Relation to Sex, 2nd ed. (John Murray, 1882).

Charles Darwin, On the Origin of Species by Means of Natural Selection, or the Preservation of Favoured Races in the Struggle for Life, Darwin Online, 1859, 254. available at: http://darwinonline.org. uk/content/frameset?viewtype=side\&itemID=F373\&pageseq=104.

Darwin, Descent of Man, and Selection in Relation to Sex, 564

Robert Trivers, Social Evolution (Menlo Park: Benjamin/Cummings Pub. Co., 1985), 333, 336.

M. J. Ryan, "Female Mate Choice in a Neo-Tropical Frog,” Science 209 (1980): 523-25.

Darwin, Descent of Man, and Selection in Relation to Sex, 211.

During the twenties of the last century, Fisher proposed an answer to this enigma when he coined the idea of the "runaway process", a hypothesis that assumes that not only traits but preferences are inherited and thus traits that are preferred have an advantage in selection. Fisher explains the case of the peacock as a result of preferences in females inherited to their daughters, and traits in males inherited to their male offspring, who will be the preferred for mating. Sir Ronald Aylmer Fisher, The Genetical Theory of Natural Selection: A Complete Variorum Edition, ed. J. H. Bennett (Oxford University Press, 1999). 
J. Shaw, "Feeling of Beauty Among Animals".

I have argued this extensively the Artistic matrix in Katya Mandoki, Everyday Aesthetics: Prosaics, the Play of Culture and Social Identities (Aldershot UK: Ashgate Pub Co, 2007). ch. 32 . Cf. Arthur Danto, “The Artworld,” The Journal of Philosophy 61, no. 19 (1964): 571-84. George Dickie, Art and the Aesthetic: An Institutional Analysis (New York: Cornell University Press, 1974).

Charles Darwin, On the Origin of Species by Means of Natural Selection, or the Preservation of Favoured Races in the Struggle for Life, Darwin Online, 1859, 89.

David Rothenberg, Why Birds Sing: A Journey Into the Mystery of Bird Song (New York: Basic Books, 2006), 9

Edward O. Wilson, Sociobiology (Cambridge: Harvard University Press, 1980), 108-09.

Darwin, Descent of Man, and Selection in Relation to Sex, 413.

Thomas A. Sebeok, "Prefigurements of Art," Semiotica - Journal of the International Association for Semiotic Studies / Revue de l'Association Internationale de Sémiotique 27, no. 1-3 (1979): $3-72$.

Charles Darwin, Descent of Man, and Selection in Relation to Sex, 2nd ed. (John Murray., 1882), 326.

Immanuel Kant, The Critique of Judgement. Trans. James Creed Meredith. Electronic version, 1790. American Philosophical Association Gopher. Section 23

Aylmer Fisher, Ronald. The Genetical Theory of Natural Selection: A Complete Variorum Edition, ed. J. H. Bennett. Oxford University Press, 1999.

Danto, Arthur. “The Artworld.” The Journal of Philosophy 61, no. 19 (1964): 571-84.

Darwin, Charles. Descent of Man, and Selection in Relation to Sex, 2nd ed.John Murray., 1882.

Darwin, Charles. On the Origin of Species by Means of Natural Selection, or the Preservation of Favoured Races in the Struggle for Life, Darwin Online, 1859, 254. available at: http://darwinonline.org. uk/content/frameset?viewtype=side\&itemID=F373\&pageseq=104.

Dickie, George. Art and the Aesthetic: An Institutional Analysis .New York: Cornell University Press, 1974.

Kant, Immanuel. The Critique of Judgement. Trans. James Creed Meredith. Electronic version, 1790. American Philosophical Association Gopher. Section 23.

Mandoki, Katya. Everyday Aesthetics: Prosaics, the Play of Culture and Social Identities. Aldershot UK: Ashgate Pub Co, 2007.

Ryan, M. J. "Female Mate Choice in a Neo-Tropical Frog." Science 209 (1980): 523-25.

Rothenberg, David.Why Birds Sing: A Journey Into the Mystery of Bird Song .New York: Basic Books, 2006.

Shaw, J. "Feeling of Beauty Among Animals," Athenceum, 1866, http:

Sebeok, Thomas A. "Prefigurements of Art." Semiotica - Journal of the International Association for Semiotic Studies/Revue de l'Association Internationale de Sémiotique 27, no. 1-3 (1979).

Trivers, Robert. Social Evolution. Menlo Park: Benjamin/Cummings Pub. Co., 1985.

Wilson, Edward O. Sociobiology .Cambridge: Harvard University Press, 1980. 


\section{IDEJA “ZDRAVOG RAZUMA" PREISPITANA: DOPRINOS “AISTETIČKOM ZAOKRETU” ESTETIKE}

\section{Tanehisa Otabe}

Mi doživljavamo "aistetički zaokret" estetike koji se fokusira niti na naš umetnički doživljaj ili stvaranje, niti na ideju lepote, već na ulogu aistetike u našem estetskom razumevanju, odnosno na našoj aistetičkoj svesti našeg bića. Cilj ovog rada je da se preispita ideja "zdravog razuma" Aristotela i Kanta, u cilju reorganizacije i reanimacije njihovih uvida i na taj način doprinosu "aistetičkom zaokretu" estetike.

Na osnovu uobičajenih verovanja, postoje dva lanca u ideji "zdravog razuma": aristotelovska ideja o nečemu intra-subjektivnom što je zajedničko različitim čulima u jednom pojedincu i ciceronska ideja nečega inter-subjektivnog što je zajedničko različitim pojedincima. Za Kantov koncept zdravog razuma smatra se da pripada drugom lancu. Za razliku od takvih uverenja, ja tvrdim sledeće: prvo, da kod Aristotela već postoji produktivna klica druge vene i, drugo, da Kantova estetika vidno nasleđuje aristotelov concept "zdravog razuma".

Šta je problem u sensus communis u širem smislu je, dakle, naša aistetička svest našeg sopstvenog bića i života. U modernoj terminologiji, upravo aistetika garantuje "osećaj realnosti” (Hana Arent (Hannah Arendt)) nas i, samim tim, i sveta u kome živimo zajedno sa drugima.

KLJUČNE REČI: AISTETIČKI ZAOKRET ESTETIKE, ZDRAV RAZUM, PERCEPCIJA PERCEPCIJE, OSEĆANJE ŽIVOTA, ESTETSKA SVEST, KO-PERCEPCIJA

\section{ESTETSKO ISKUSTVO U KONTINUUMU PRIRODA-KULTURA. BIOLOŠKA DIMENZIJA PRAGMATIČKE ESTETIKE Krystyna Wilkoszewska}

Godine 1930. američki pragmatički filozof Džon Djui (John Dewey) uveo je u estetiku relativno novu ideju iskustva. Živeći u savremenom vremenu Djui je ponudio ne-modernistički način razmišljanja koji posebno u oblasti estetike izgleda kao adekvatniji našem vremenu u poređenju sa modernim idejama estetskog doživljaja i autonomije umetnosti. Nakon kratke prezentacije Djuieve filozofije estetike želim da pokažem njene unutrašnje dimenzije koje su u potpunosti razvijene danas: ekološke, evolucione i transhumanističke tendencije, iskustvo kao interakcija, soma i senzualna perspektiva.

KLJUČNE REČI: PRAGMATIZAM, SOMAESTETIKA, EVOLUCIJA, ŽIVOTINJSKA ESTETIKA

\section{STANJE ESTETIKE DANAS}

\section{Katya Mandoki}

U ovom radu moja zalaganja idu u smeru proširenja polje estetike ne samo izvan umetnosti i lepote, već i izvan svakodnevne estetike (ili prozaička) fokusirane na ljudsku osećajnost. To podrazumeva razmatranje senzibiliteta ili aesthesis u svim živim bićima kako bi se razumela beskonačnost bio-estetike. Te je deo ovog izlaganja zoo-estetika. Sve je više dokaza iz dana u dan koji potvrđuju postojanje senzibiliteta životinja, sposobnost da stvaraju, imitiraju, iskuse, izlože i izraze senzibilitet ili estetski ukus u različitim oblicima, te je teže negirati što više pratimo i svedočimo njihovom ponašanju. Štaviše, kako postoje različiti umetnički žanrovi, možemo jednako govoriti o sličnim žanrova u zoo-poetici, i to: a) muzički, b)vizualni (i arhitektonski i dekorativni), c) dramski, d) plesni.

Da li su ženke zaslepljene od strane muškog slepog miša ili ptičjom pesmom parenja? Da li paunice osećaju zadovoljstvo kada ugledaju rep muškog pauna? Kao što Najdžel (Nagel) pita 'kako je biti slepi miš?’ Zaista bih volela da znam kako je biti paunica. 
Kompletno istraživanja objavljeno je u knjizi The indispensable excess of the aesthetics: evolution of sensibility in nature (Neizostavni višak estetike: Evolucija senzibiliteta u prirodi, Lexington 2015).

KLJUČNE REČI: EVOLUTIVNA ESTETIKA, DARVIN, BIOSEMIOTIKA, ZOO-POETIKA, AESTHESIS, ZOO-ESTETIKA, EVOLUCIJA

\section{OBECANJE MEDIJSKE ARHEOLOGIJE Nadežda Čačinovič}

Medijska arheologija nudi novi i neophodan alat za suočavanje sa mnoštvom fenomena koje tako neselektivno - anahrono ili na druge načine - prepoznajemo kao umetnost i klasifikujemo kao umetnička dela. Rad pokušava da naglasi razliku u poređenju sa srodnim gledištim: teorije kulturne transmisije, materijalnosti kulture, logike estetskih režima itd. Moglo bi se nazvati "mediji pre medija" (i prati Kitlera (Kittler)) ili kopati sa Zilinskim u "Duboko vreme medija" (Deep Time of the Media) sa dobrom vezom prema "istoriji pristupa čula" ili ići pravo sa Jusi Parikom i Erki Huhtamom (Jussi Parikka, Erkki Huhtamo) i koristiti "medijsku arheologiju”: ali je uvek priznanje protejske prirode umetnosti i arhitekture.

KLJUČNE REČI: MATERIJALNOST KULTURE, ISTORIJA ČULA, MEDIJI, KULTURNA TRANSMISIJA

\section{FORMA I ZNAČENJE U ARHITEKTONSKOJ TEORIJI Jale Nejdet Erzen}

Često je arhitektonska teorija bilo jasno izražena propisanim stavovima o tome šta bi arhitektura trebalo da bude, pre nego stavovima formulisanim od istorijskih iskustava i primera arhitekture. U ovom radu ću pokušati da ponudim čitanje arhitektonske forme gledajući istorijski primer iz klasične otomanske arhitekture i savremene primere, pokazujući kako različite arhitekture tretiraju formu. U primerima Sinanove arhitekture, simboli su istraživani u odnosu na kretanje, urbani sklop, religiju i moć. Ideja je da će ova analiza ponuditi razumevanje značaja arhitekture u okvirima ljudskog iskustva i urbanog konteksta kojii dopire izvan strukture i funkcije.

KLJUČNE REČI: ARHITEKTURA, SINAN, FORMA, ZNAČENJE, STRUKTURA, TELESNI ODNOSI

\section{POL ŠIRBART I UTOPIJA OD STAKLA}

\section{Tyrus Miller}

Ovaj rad će razmotriti arhitektonske spise nemačkog ekspresionističkog pisca Pola Širbarta (Paul Scheerbart), sa fokusom na njegovoj fascinaciji staklom kao arhitektonskim i metaforičkim materijalom. Diskusija je o Širbartovom arhitektonskom traktatu Arhitektura stakla (Glass Architecture), njegovom romanu Siva tkanina (The Grey Cloth) i srodnim tekstovima o arhitekturi stakla. Širbart predstavlja alternativnu tradiciju unutar arhitektonskog modernizma, koja gleda na staklo kao na konstruktivan materijal koji predstavlja modernost kroz izlaganje strukturalnih elemenata, takođe u službi komfor forme prema funkciji. Širbart, nasuprot tome, smatra staklo nosiocem boje i multiplikatora svetlosti, koje je video kao sposobnog da transformiše čovekovu okolinu i ostvari pozitivne efekte na pojedince i kolektive. On je video svetlost kao kulturnoformativnu, a arhitekturu stakla kao sredstvo kojim izgrađeno okruženje može da poveća moderni kulturalni utopijski potencijal. Takođe, ukratko ću razmotriti i uticaj Širbarta na anarhističkog arhitektu Bruna Tauta (Bruno Taut) i na razmišljanja Valtera Benjamina (Walter Benjamin). 